International Journal of Environmental Research and

Article

\title{
Occurrence of Vibrio Pathotypes in the Final Effluents of Five Wastewater Treatment Plants in Amathole and Chris Hani District Municipalities in South Africa
}

\section{Vuyokazi Nongogo * and Anthony I. Okoh}

Applied and Environmental Microbiology Research Group (AEMREG), Department of Biochemistry and Microbiology, University of Fort Hare, Alice 5700, South Africa; E-Mail: AOkoh@ ufh.ac.za

* Author to whom correspondence should be addressed; E-Mail: vnongogo@ufh.ac.za;

Tel.: +27-(0)-40-602-2365; Fax: +27-(0)-866-286-824.

Received: 3 June 2014; in revised form: 16 July 2014 / Accepted: 25 July 2014 /

Published: 4 August 2014

Abstract: We assessed the occurrence of Vibrio pathogens in the final effluents of five wastewater treatment plants (WWTPs) located in Amathole and Chris Hani District Municipalities in South Africa over a 12 months period between September 2012 and August 2013 using standard membrane filtration technique followed by cultivation on thiosulphate citrate-bile salts-sucrose (TCBS) agar. The identities of the presumptive Vibrio isolates were confirmed using polymerase chain reaction (PCR) including delineation into V. parahaemolyticus, V. vulnificus and V. fluvialis pathotypes. The counts of Vibrio spp. varied with months in all the study sites and ranged in the order of $10^{1}$ and $10^{4} \mathrm{CFU} / 100 \mathrm{~mL}$. Vibrio distribution also showed seasonality with high counts being obtained in autumn and spring $(p<0.05)$. Prevalence of Vibrio spp. among the five WWTPs also differed significantly $(p<0.05)$. Of the 300 isolates that were confirmed as belonging to the Vibrio genus, 29\% (86) were V. fluvialis, 28\% (84) were V. vulnificus and $12 \%$ (35) were $V$. parahaemolyticus. The isolation of Vibrio pathogens from the final effluent suggests that this pathogen is in circulation in some pockets of the population and that the WWTPs under study do not efficiently remove bacterial pathogens from the wastewater and consequently are threats to public health.

Keywords: wastewater treatment plant; effluents; Vibrio pathotypes 


\section{Introduction}

Wastewater production is a common phenomenon worldwide and regulatory imperatives demands that wastewater be treated before discharge into the environment [1]. Unfortunately, many wastewater treatment plants still discharge significant amounts of fecal coliforms and pathogenic microorganisms which impair the quality of water in the receiving watersheds [2]. The impaired quality of these final effluents is usually brought about by the poor operational state and inadequate maintenance of most of these municipalities' sewage treatment works resulting in production of effluents of poor quality [3] thus impacting negatively on the receiving watersheds. Wastewater final effluents therefore serve as reservoirs of many enteric pathogens [4] especially also capitalizing on their enhanced strategies to survive wastewater treatment processes and reduced susceptibilities to disinfectants [5]. Of these enteric pathogens, the Vibrio genus has been one of the major pathogens known to cause outbreaks worldwide, but mostly known for causing cholera [6]. The genus Vibrio is a member of the family Vibrionaeceae which includes opportunistic pathogens of humans and animals [7]. They are marine in origin, and commonly associated with aquatic living species [8]. Although they can be pathogens for humans and aquatic animals, their role in the marine environment has been shown to include biodegradation, nutrient regeneration and biogeochemical cycling [9]. Their adaptability to adverse conditions has promoted wide distribution of vibrios in effluent environments associated with domestic sewage [10]. Previous research has focused mostly on Vibrio cholera in water because of the severity of the disease it causes [11], but over the last decade, several studies have involved relatively minor Vibrio species of medical interest [7], some of which are described as emerging pathogens able to cause mild to severe human diseases [12].

Several species of Vibrio are pathogens, including V. parahaemolyticus, V. fluvialis and V. vulnificus which is common in warm seawater and thrives in water temperatures greater than $20{ }^{\circ} \mathrm{C}$ [13]. This pathogen is directly associated with pollution or fecal waste and in most cases, causes disease in individuals who eat contaminated seafood (usually raw or undercooked oysters) or have an open wound that is exposed to seawater [14]. The result of exposure to V. vulnificus usually results in wound infections, gastroenteritis, or primary septicaemia [15]. Vibrio parahaemolyticus occupies a variety of niches and is a common bacterium in marine and estuarine environments [16]. Though this organism is recognized as a major worldwide cause of gastroenteritis, particularly in areas of the world where seafood consumption is high [17], an interesting study by Tunung et al. [18] has reported prevalence of $V$. parahaemolyticus also in raw vegetables from retail shops. Vibrio fluvialis is a halophilic Vibrio species that has been associated with sporadic outbreaks of diarrhoea worldwide [19-21], and is clinically very similar to cholera. V. fluvialis can also pose a significant economic threat to aquaculture since it is pathogenic to cultured fish and lobsters [22]. Infections by $V$. fluvialis are generally common in infants, children, and young adults [23].

Studies concerning Vibrio pathogens have focused mainly on seafood and the marine environment. There is a dearth of information on the incidence of Vibrio species in wastewater effluents worldwide and to the best of our knowledge, only studies from our group [24,25] have reported on wastewater effluent vibriology in South Africa, albeit in two facilities, and the question of how widespread this phenomenon is in the Eastern Cape Province of South Africa became a motivation for this current study. In this paper, we evaluate the occurrence of Vibrio pathotypes in the final effluents of five 
wastewater treatment plants in the Amathole and Chris Hani district municipalities in the Eastern Cape Province as part of our larger study on wastewater effluents vibriology in South Africa.

\section{Experimental Section}

\subsection{Description of Study Site}

The 5 WWTPs are located in Amathole (Plants E, M and R) and Chris Hani (Plants Q and W) district municipalities in the Eastern Cape Province of South Africa which is one of the poorest and second largest provinces in South Africa, mainly comprised of rural settlements with little or no adequate sanitary facilities [26]. Plant $\mathrm{M}$ and Plant $\mathrm{W}$ use biofilter treatment technology while Plant R, Plant E and Plant Q use activated sludge systems. The operational characteristics of the plants are as articulated in Table 1.

Table 1. Some characteristics of the WWTPs.

\begin{tabular}{|c|c|c|c|c|c|}
\hline \multirow{2}{*}{ WWTP } & \multicolumn{3}{|c|}{ Amathole D.M WWTPs } & \multicolumn{2}{|c|}{ Chris Hani D.M WWTPs } \\
\hline & Plant M & Plant R & Plant E & Plant W & Plant Q \\
\hline Technology & $\begin{array}{l}\text { Biofilters, anaerobic } \\
\text { digestion and sludge } \\
\text { drying beds }\end{array}$ & $\begin{array}{l}\text { Activated sludge and } \\
\text { sludge lagoons }\end{array}$ & $\begin{array}{l}\text { Activated sludge and } \\
\text { marine outfall }\end{array}$ & $\begin{array}{l}\text { Biofilters, sludge } \\
\text { composting }\end{array}$ & $\begin{array}{c}\text { Biofilters, anaerobic } \\
\text { digestion }\end{array}$ \\
\hline Design Capacity (ML/d) & 24 & 2.5 & 40 & 4.99 & $\mathrm{NI} *$ \\
\hline $\begin{array}{c}\text { Operational \% in relation } \\
\text { to Design Capacity }\end{array}$ & $43.8 \%$ & $44 \%$ & $85.5 \%$ & $50.1 \%$ & $\mathrm{NI} *$ \\
\hline
\end{tabular}

$\mathrm{NI} *$ denotes that No Information was provided on Plant Q from the DWAF Greendrop report of 2012.

\subsection{Sample Collection}

Wastewater final effluent samples were collected aseptically from the final effluents using sterile $1000 \mathrm{~mL}$ glass bottles containing $1.7 \mathrm{~mL}$ of $1 \%$ sodium thiosulfate for de-chlorination. Samples were transported on ice to the laboratory of the Applied and Environmental Microbiology Research Group (AEMREG) at the University of Fort Hare for analysis within $6 \mathrm{~h}$ of collection.

\subsection{Enumeration and Isolation of Presumptive Vibrio Species}

Vibrio bacteria count was done using the membrane filtration method. Briefly, $100 \mathrm{~mL}$ of appropriately diluted effluent samples was filtered through a $0.45 \mu \mathrm{m}$ size membrane filters under vacuum. The membrane filter was then transferred onto thiosulphate citrate bile salts sucrose (TCBS) agar plates and incubated at $37^{\circ} \mathrm{C}$ for up to $48 \mathrm{~h}$. At the end of the incubation period, typical yellow and green colonies were counted as presumptive Vibrio species and expressed as colony forming units per $100 \mathrm{~mL}$ (CFU/100 mL). Five to 10 isolated colonies per plate were then randomly picked and subsequently subcultured on sterile TCBS agar plates for purity. Pure isolates were then plated on nutrient agar plants, incubated overnight as before and from there glycerol stocks (20\%) were prepared and stored at $-80{ }^{\circ} \mathrm{C}$ for further analysis. 


\subsection{Molecular Confirmation of Pathogenic Vibrio Species}

Variable regions around positions of 700 and 1325 within the 16S rRNA gene were used as target sequences to confirm the identities of the presumptive Vibrio isolates to the genus level using specific primers in the polymerase chain reaction (PCR) assay [27]. PCR was also done to further delineate the confirmed Vibrio isolates into V. fluvialis, V. vulnificus and $V$. parahaemolyticus species using species-specific primers targeting the different regions of the tox $R$ and $h s p 60$ gene as presented in Table 2. To isolate the genomic DNA the method of Maugeri et al. [28] was followed. Single colonies of presumptive Vibrio grown overnight at $37{ }^{\circ} \mathrm{C}$ on nutrient agar plates were picked, suspended in $200 \mu \mathrm{L}$ of sterile distilled water and the cells lysed using AccuBlock (Digital dry bath, Labnet) for $15 \mathrm{~min}$ at $100{ }^{\circ} \mathrm{C}$. The cell debris was removed by centrifugation at $11000 \times g$ for 2 min using a MiniSpin micro centrifuge. The cell lysates $(5 \mu \mathrm{L})$ was used as template in the PCR assays immediately after extraction. The thermal cycling profile was as follows: a single round of enzyme activation for $15 \mathrm{~min}$ at $93{ }^{\circ} \mathrm{C}$ followed by 35 cycles at $92{ }^{\circ} \mathrm{C}$ for $40 \mathrm{~s}, 57{ }^{\circ} \mathrm{C}$ for $1 \mathrm{~min}$ and $72{ }^{\circ} \mathrm{C}$ for $1.5 \mathrm{~min}$ and final extension at $72{ }^{\circ} \mathrm{C}$ for $7 \mathrm{~min}$.

Table 2. Sets of primers used for identification and pathotyping of Vibrio species.

\begin{tabular}{cccccc}
\hline Target Species & Primers & Sequences (5'3') & $\begin{array}{c}\text { Target } \\
\text { Gene }\end{array}$ & $\begin{array}{c}\text { Amplicon } \\
\text { Size (bp) }\end{array}$ & Reference \\
\hline \multirow{2}{*}{ All Vibrio spp. } & V. 16S-700F & CGG TGA AAT GCG TAG AGA T & 16SrRN & \multirow{2}{*}{663} & {$[27]$} \\
& V. 16s-1325R & TTA CTA GCG ATT CCG AGT TC & A & & \\
V. parahaemolyticus & Vp.toxR R & GTC TTC TGA CGC AAT CGT TG & toxR & 368 & {$[29]$} \\
& Vp.toxR F & ATA CGA GTG GTT GCT GTC ATG & & & \\
V. vulnificus & Vv. hsp-326F & GTC TTA AAG CGG TTG CTG C & hsp60 & 410 & {$[30]$} \\
& Vv. hsp-697R & CGC TTC AAG TGC TGG TAG AAG & & & \\
V. fluvialis & Vf- toxR F & GAC CAG GGC TTT GAG GTG GAC & toxR & 217 & {$[31]$} \\
& Vf- toxR R & AGG ATA CGG CAC TTG AGT AAG ACT C & &
\end{tabular}

\section{Results and Discussion}

Vibrio densities during the study period ranged between $1-1.48 \times 10^{4} \mathrm{CFU} / 100 \mathrm{~mL}$. High densities of $1.28 \times 10^{4} \mathrm{CFU} / 100 \mathrm{~mL}$ and $1.48 \times 10^{4} \mathrm{CFU} / 100 \mathrm{~mL}$ were obtained for the months of November 2012 and May 2013 at Plant E and Plant Q WWTPs, respectively as shown in Table 3. 
Table 3. Occurrence of Vibrio spp. in selected WWTPs from the Amathole and Chris District Municipalities.

\begin{tabular}{|c|c|c|c|c|c|c|c|c|c|c|c|c|}
\hline \multicolumn{13}{|c|}{ Vibrio spp. (CFU/100 mL) } \\
\hline WWTP & SEPT' 12 & OCT'12 & NOV'12 & DEC ' 12 & JAN'13 & FEB'13 & MAR'13 & APR'13 & MAY'13 & JUNE' '13 & JULY'13 & AUG'13 \\
\hline PLANT M & $9.2 \times 10^{2}$ & $4.8 \times 10^{1}$ & $6.2 \times 10^{2}$ & $1.6 \times 10^{2}$ & $1.0 \times 10^{2}$ & $2.6 \times 10$ & $5.2 \times 10^{2}$ & $6.0 \times 10^{1}$ & $1.3 \times 10^{1}$ & $1.4 \times 10^{1}$ & $9.5 \times 10^{1}$ & $1.3 \times 10^{1}$ \\
\hline PLANT R & $<1$ & $<1$ & $1.3 \times 10^{0}$ & $2 \times 10^{0}$ & $1 \times 10^{0}$ & $<1$ & $<1$ & $8.7 \times 10^{0}$ & $9 \times 10^{\circ}$ & $<1$ & $5 \times 10^{0}$ & $<1$ \\
\hline PLANT E & $3.6 \times 10^{1}$ & $8.5 \times 10^{2}$ & $1.28 \times 10^{4}$ & $6.1 \times 10^{2}$ & $5.2 \times 10^{2}$ & $3.5 \times 10^{1}$ & $6.2 \times 10^{1}$ & $7.7 \times 10^{3}$ & $6.0 \times 10^{1}$ & $3.5 \times 10^{2}$ & $4.5 \times 10^{3}$ & $1.29 \times 10^{3}$ \\
\hline PLANT W & $\mathrm{N} / \mathrm{S}$ & $1.14 \times 10^{2}$ & $1.61 \times 10^{2}$ & $1.8 \times 10^{2}$ & $4.0 \times 10^{1}$ & $3.9 \times 10^{1}$ & $7.2 \times 10^{1}$ & $1.6 \times 10^{1}$ & $2.1 \times 10^{1}$ & $<1$ & $1.6 \times 10^{1}$ & $7 \times 10^{0}$ \\
\hline PLANT Q & $6.8 \times 10^{1}$ & $3.4 \times 10^{2}$ & $2.26 \times 10^{3}$ & $1.48 \times 10^{3}$ & $9.6 \times 10^{1}$ & $8.3 \times 10^{3}$ & $1.24 \times 10^{3}$ & $5.8 \times 10^{1}$ & $1.48 \times 10^{4}$ & $2.5 \times 10^{1}$ & $1 \times 10^{0}$ & $<1$ \\
\hline
\end{tabular}

$\mathrm{NS}=$ not sampled; CFU = colony forming units; WWTP = wastewater treatment plant; $<=$ less than. 
Plant Q was noted to have challenges with the pipeline system necessitating upgrading of the plant between the months of September 2012-May 2013. As shown in Table 3, the highest counts of presumptive Vibrio species were obtained in the months when maintenance work was ongoing. However, after the refurbishment of Plant $\mathrm{Q}$, the plant had major improvements and experienced counts as low as $1 \mathrm{CFU} / 100 \mathrm{~mL}$ in July 2013 and $<1 \mathrm{CFU} / 100 \mathrm{~mL}$ in August 2013. One other possibility of the reduction in the Vibrio counts could be the winter season which normally starts from June to August and characterized by low temperatures in South Africa. Similar studies by Igbinosa et al. [24] showed that the abundance of Vibrio species in the final effluents was linked to temperature, while its relationship to salinity is less clear. The remaining WWTPs, i.e., Plant M and Plant W, were also characterized with high Vibrio counts in the order of $10^{2} \mathrm{CFU} / 100 \mathrm{~mL}$. The Vibrio counts in Plant $\mathrm{M}$ did not follow any defined pattern and fluctuated throughout the sampling period and suspected to be related to irregular and inadequate chlorine disinfectant dosing regimens. Also, the presence of a kraal nearby suggest the possibility of post-treatment contamination of the final effluent tank by run-offs from the kraal as suggested by the report of Uddin et al. [32] on the prevalence of Vibrio from cow dung and excreta of poultry samples.

With respect to season, the Vibrio counts (Figure 1) varied significantly ( $p \leq 0.05$ ), and was highest in autumn for Plant Q $\left(5.4 \times 10^{3} \mathrm{CFU} / 100 \mathrm{~mL}\right)$ and in spring for Plant E $\left(4.6 \times 10^{3} \mathrm{CFU} / 100 \mathrm{~mL}\right)$. However, Plant R recorded the lowest Vibrio counts throughout the seasons. There was a similar trend in Plants E, M and W where the highest mean counts were obtained during spring and the lowest mean counts in winter. These findings corroborate the observations of Lin and Schwarz [33] who reported that $V$. vulnificus was not detected during the winter months but abundantly isolated in the spring months. Maugeri et al. [34] also has confirmed that the distribution of pathogenic Vibrio spp. in aquatic environments is greatly influenced by temperature. Plant $\mathrm{R}$ and Plant $\mathrm{Q}$ had their highest mean Vibrio densities in autumn. The lowest mean counts were obtained in winter for Plant $\mathrm{Q}$ and in spring and summer for Plant R.

Molecular confirmation of the presumptive Vibrio isolates resulted in the confirmation of 300 isolates as belonging to the Vibrio genus as shown in Figure 2.

About $29 \%$ of the isolates were found to be V. fluvialis, while $28 \%$ were V. vulnificus and $11.6 \%$ were $V$. parahaemolyticus. The remaining isolates $(31.8 \%)$ belonged to other species that were not assayed for in this study. The identities of $V$. fluvialis and $V$. parahaemolyticus were confirmed by use of species-specific primers targeting the different regions of the toxR gene. Identification of the confirmed isolates into respective Vibrio pathotypes reveals the presence of potentially pathogenic strains for humans and animals. Gel electrophoresis of the species delineation PCRs are as shown in Figures 3-5.

It is known that among vibrios, these three species can adapt themselves to adverse conditions e.g., organic matter limited environments by means of survival strategies such as adhering to different substrata $[28,35]$ hence survival of these pathogenic vibrios in wastewater treatment plants is possible. The most prevalent species detected was $V$. fluvialis followed by $V$. vulnificus and V. parahaemolyticus. Previous reports have articulated the isolation of Vibrio species from different niches and geographical regions. In marine environments of Italy Gugliandolo et al. [35] found V. vulnificus as a dominant species, while Sousa et al. [36] isolated V. parahaemolyticus and V. cholera in oysters collected in 
Brazil. Also Tuning et al. [18] has highlighted the prevalence of $V$. parahaemolyticus in raw vegetables.

Figure 1. Seasonal distribution of Vibrio spp. in selected wastewater treatment plants.

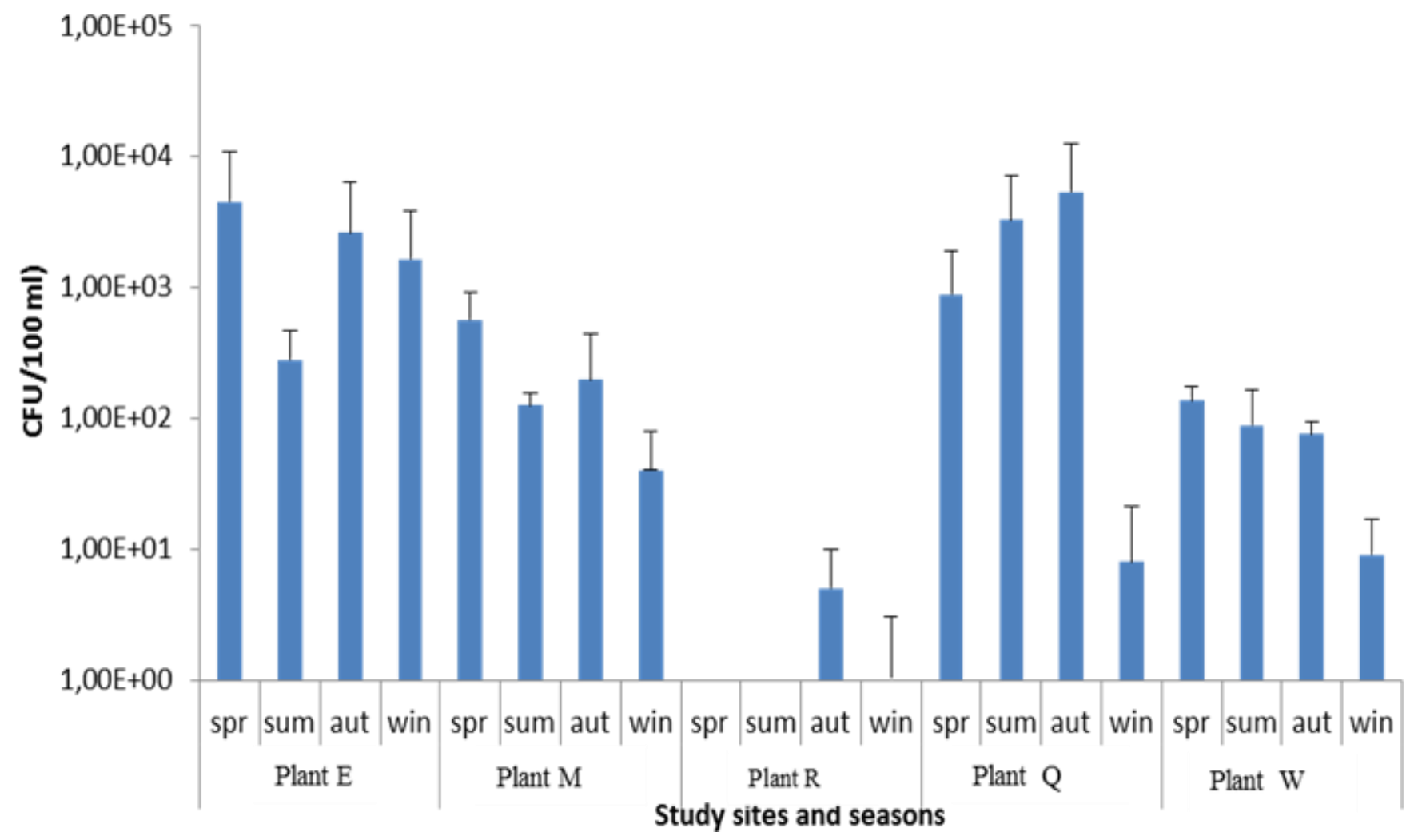

Figure 2. Gel electrophoresis of the PCR products of some of the confirmed Vibrio spp. Lane 1: Gene ruler (100 bp); Lane 2: Positive (+ve) control V. fluvialis; Lane 3: Negative control; Lane 4-13 (Samples).

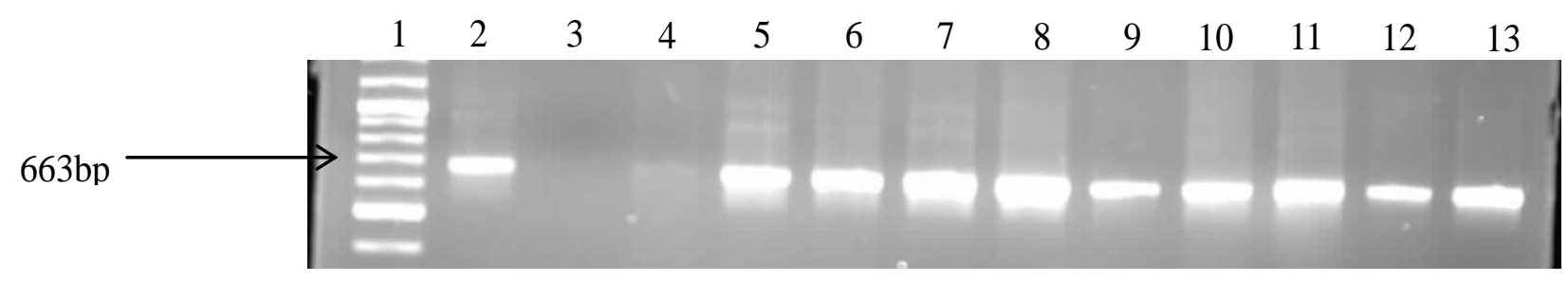


Figure 3. Gel electrophoresis of PCR products of some of the confirmed $V$. parahaemolyticus.

Lane 1: Gene ruler (100 bp); Lane 2: Positive control (V. parahaemolyticus DSM 11058); Lane 3 (Negative control); Lane 4-13 (Samples).

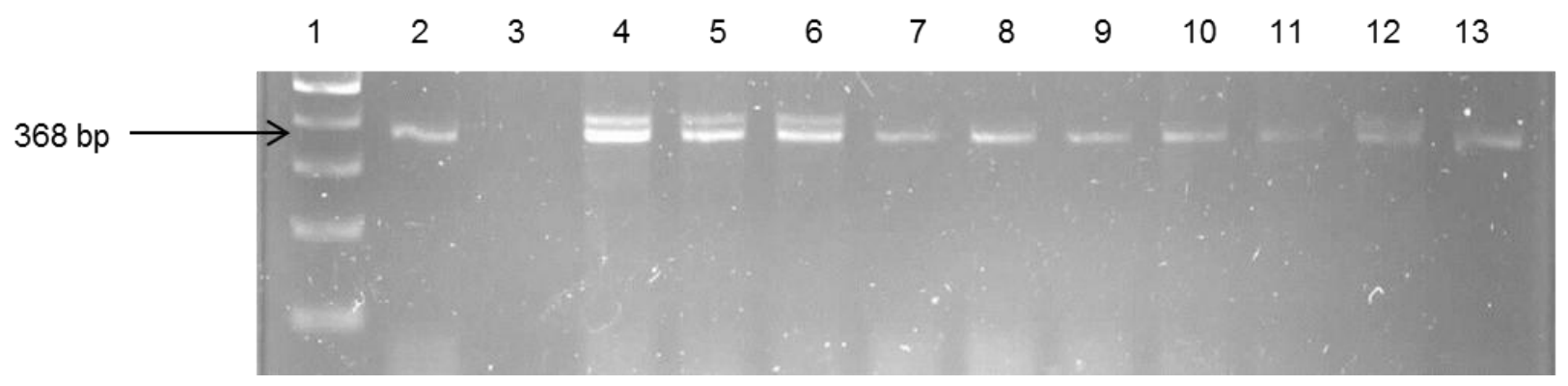

Figure 4. Gel electrophoresis of PCR products of some of the confirmed V. fluvialis. Lane 1: Gene ruler (100 bp); Lane 2: Positive control (V. fluvialis DSM 19283); Lane 3 (Negative control); Lane 4-11 (Samples).

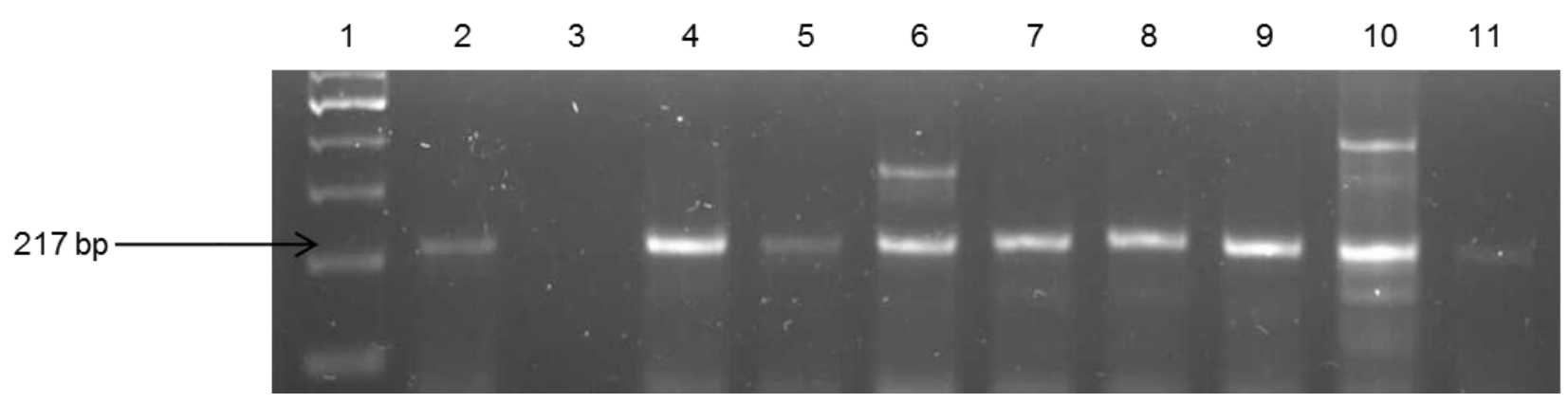

Figure 5. Gel electrophoresis of PCR products of some of the confirmed V. vulnificus. Lane 1: Gene ruler (100 bp); Lane 2: Positive (+ve) control V. vulnificus (410 bp); Lane 3 (Negative control); Lane 4-13 (Samples).

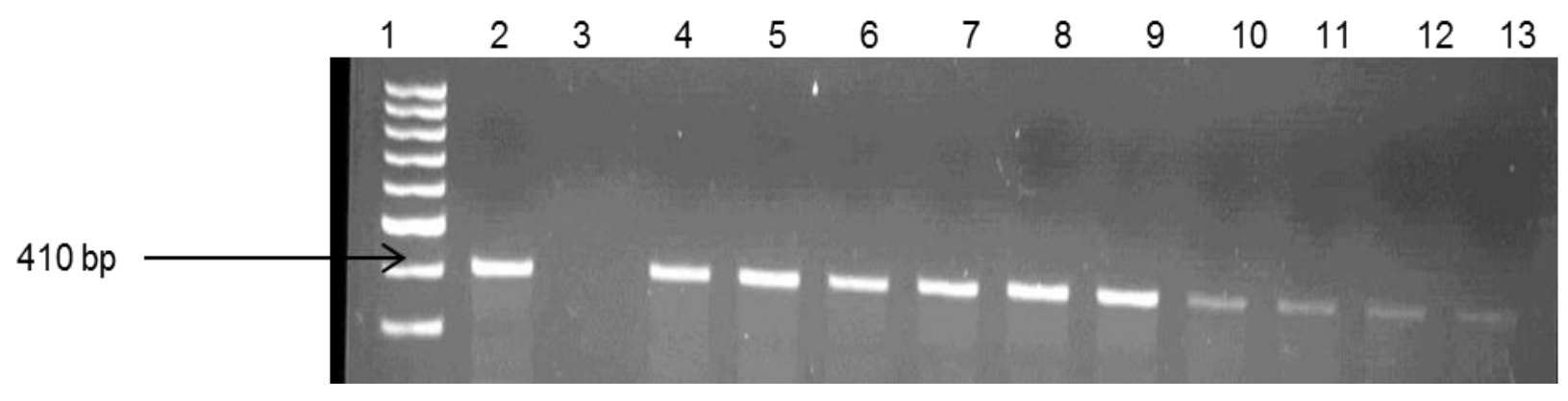

It has also been reported that human activity can greatly enhance the global transport of marine species [37] including pathogenic strains and may have contributed to the isolation of Vibrio in the final effluents. Findings of Kelly and Stroh [38] from Pacific Northwest showed that oysters are the main source of $V$. fluvialis and other vibrios especially during warmer seasons. The dangers which come with the abundance of $V$. fluvialis is the production of an enterotoxin known to cause a serious infection, as its clinical symptoms of gastroenteritis are very similar to those caused by $V$. cholera $\mathrm{O} 1$ and non-O1 strains [19]. According to a recent study Liang et al. [39], Vibrio fluvialis has been considered to be an emerging food borne pathogen and has become a high human public health hazard 
all over the world, especially in coastal areas of developing countries and regions with poor sanitation. Isolation of $V$. fluvialis in large numbers can pose a significant economic threat for aquaculture in areas where seafood consumption is high, making a cycle back to faecal waste and final effluents [22]. Similarly, both $V$. vulnificus and $V$. parahaemolyticus are also food borne pathogens which are associated with raw seafood causing 3 major syndromes of clinical illness, i.e., gastroenteritis, wound infections, and septicaemia [40]. V. parahaemolyticus has been often isolated from seafood, including shrimp, in markets in South East Asian countries [41] and previous studies at markets in China have shown $V$. vulnificus as dominant in cultured shrimps [42,43].

\section{Conclusions}

In this study, the presence of Vibrio pathogens mainly $V$. fluvialis, $V$. vulnificus and $V$. parahaemolyticus in the final effluents of WWTPs suggest that wastewater effluents are important reservoirs of Vibrio pathotypes and potential source of the same in the watershed. The presence of these pathogens in high densities also suggest the inefficiency of the treatment plants to adequately remove microbial pathogens from wastewater, and as such, constitute a threat to public and environmental health. The need for regular monitoring of the treatment works to ensure compliance to set guidelines becomes imperative and here recommended.

\section{Acknowledgments}

We are grateful to the Water Research Commission (WRC) of South Africa for funding this study through grant K5/2145. VN is also grateful to the National Research Foundation (NRF) of South Africa for Master's Bursary support.

\section{Author Contributions}

Nongogo Vuyokazi: Executed the research, analyzed the experimental data and prepared the first manuscript. Anthony I. Okoh: Planned and designed the research and supervised Nongogo Vuyokazi.

\section{Conflicts of Interest}

The authors declare no conflict of interest.

\section{References}

1. Department of Water Affairs and Forestry, (DWAF). South African water quality guidelines. In Domestic Uses, Department of Water Affairs and Forestry; Holmes, S., Ed.; DWAF: Pretoria, South Africa, 1996; pp. 132-135. Available online: http://www.dwaf.gov.za/iwqs/ wq_guide/Pol_saWQguideFRESH_vol6_AquaCulture.pdf (accessed on 17 November 2013).

2. Bahlaoui, M.A.; Baleux, B.; Troussellier, M. Dynamics of pollution indicators and pathogenic bacteria in high rate oxidation wastewater treatment ponds. Water Res. 1997, 31, 574-582. 
3. Momba, M.N.B.; Osode, A.N.; Sibewu, M. The impact of inadequate wastewater treatment on the receiving water bodies - Case study: Buffalo City and Nkonkobe Municipalities of the Eastern Cape Province. Water SA 2006, 32. Available online: http://www.ewisa.co.za/literature/files/ 275\%20Momba.pdf (accessed on 3 June 2014).

4. Shuval, H.; Badri, F. Handbook of Water and Wastewater Microbiology, 1st ed.; Academic Press: San Diego, CA, USA, 2003; pp. 241-262.

5. Donlan, R.M. Biofilms: Microbial life on surfaces. Emerg. Infect. Dis. 2002, 8, 881-890.

6. Griffith, D.C.; Kelly-Hope, L.A.; Miller, M.A. Review of reported cholera outbreaks worldwide, 1995-2005. Am. J. Trop. Med. Hyg. 2006, 75, 973-977.

7. Daniels, N.A.; MacKinnon, L.; Bishop, R.; Altekruse, S.; Ray, B.; Hammond, R.M.; Slutsker, L. Vibrio parahaemolyticus infections in the United States, 1973-1998. J. Infect. Dis. 2002, 181, 1661-1666.

8. Thompson, J.R.; Randa, M.A.; Marcelino, L.A.; Tomita-Mitchell, A.; Lim, E.; Polz, M.F. Diversity and dynamics of a North Atlantic coastal Vibrio community. Appl. Environ. Microbiol. 2004, 70, 4103-4110.

9. Cavallo, R.N.; Loredana, S. Culturable vibrios biodiversity in the Northern Ionian Sea (Italian coasts). Sci. Mar. 2004, 68, 23-29.

10. Mezrioui, N.; Oufdou, K. Abundance and antibiotic resistance of non-O1 Vibrio cholerae strains in domestic wastewater before and after treatment in stabilization ponds in an arid region (Marrakesh, Morocco). FEMS Microbiol. Ecol. 1996, 21, 277-284.

11. Mishra, M.; Mohammed, F.; Akulwar, S.L.; Katkar, V.J.; Tankhiwale, N.S.; Powar, R.M. Re-emergence of El Tor Vibrio in outbreak of cholera in and around Nagpur, Indian. J. Med. Res. 2004, 120, 478-480.

12. Tantillo, G.M.; Fontanarosa, M.; Di Pinto, A.; Musti, M. Updated perspectives on emerging vibrios associated with human infections. Lett. Appl. Microbiol. 2004, 39, 117-126.

13. Bross, M.H.; Soch, K.; Morales, R.; Mitchell, R.B. Vibrio vulnificus infection: Diagnosis and treatment. Am. Fam. Physician 2007, 76, 539-544.

14. Anuradha De, M.M. Vibrio vulnificus diarrhea in a child with respiratory infection. J. Glob. Infect. Dis. 2011, 3, 300-302.

15. Morris, J.G. Vibrio vulnificus-A new monster of the deep? Ann. Intern. Med. 1988, 109, 261-263.

16. McCarter, L. The multiple identities of Vibrio parahaemolyticus. J. Mol. Microbiol. Biotechnol. 1991, 1, 51-57.

17. Nair, G.B.; Ramamurthy, T.; Bhattacharya, S.K.; Dutta, B.; Takeda, Y.; Sack, D.A. Global dissemination of Vibrio parahaemolyticus serotype O3: K6 and its serovariants. Clin. Microbiol. Rev. 2007, 20, 39-48.

18. Tunung, R.; Ghazali, F.M.; Noranizan, M.A.; Haresh, K.K.; Lesley, M.B.; Nakaguchi, Y.; Son, R. Rapid detection and enumeration of pathogenic Vibrio parahaemolyticus in raw vegetables from retail outlets. Int. Food Res. J. 2011, 18, 67-78.

19. Huq, M.I.; Alam, A.K.; Brenner, D.J.; Morris, G.K. Isolation of Vibrio-like group, EF-6, from patients with diarrhea. J. Clin. Microbiol. 1980, 5, 621-624. 
20. Hlady, W.G.; Klontz, K.C. The epidemiology of Vibrio infections in Florida, 1981-1993. J. Infect. Dis. 1996, 173, 1176-1183.

21. Lesmana, M.; Subekti, D.S.; Tjaniadi, P.; Simanjuntak, C.H.; Punjabi, N.H.; Campbell, J.; Rand Oyofo, B.A. Spectrum of Vibrio species associated with acute diarrhea in North Jakarta, Indonesia. Diagn. Microbiol. Infect. Dis. 2002, 43, 91-97.

22. Tall, B.D.; Fall, S.; Pereira, M.R.; Ramos-Valle, M.; Curtis, S.K.; Kothary, M.H.; Chu, D.M.; Monday, S.R.; Kornegay, L.; Donkar, T.; et al. Characterization of Vibrio fluvialis-like strains implicated in limp lobster disease. Appl. Environ. Microbiol. 2003, 5, 7435-7446.

23. Chakraborty, R.; Chakraborty, S.; De, K.; Sinha, S.; Mukhopadhyay, A.K.; Khanam, J.; Ramamurthy, T.; Takeda, Y.; Bhattacharya, S.K.; Nair, G.B. Cytotoxic and cell vacuolating activity of Vibrio fluvialis isolated from paediatric patients with diarrhoea. Int. J. Med. Microbiol. 2005, 8, 707-716.

24. Igbinosa, E.O.; Obi, C.L.; Okoh, A.I. Occurrence of potentially pathogenic vibrios in the final effluents of a wastewater treatment facility in a rural community of the Eastern Cape Province of South Africa. Res. Microbiol. 2009, 160, 531-537.

25. Igbinosa, E.O.; Okoh, A.I. Vibrio fluvialis: An unusual enteric pathogen of increasing public health concern. Int. J. Environ. Res. Public Health 2010, 7, 3628-3643.

26. Mafuya, P.N.; Shukla, N. Factors that could motivate people to adopt safe hygienic practices in the Eastern Cape Province, South Africa. Afr. Health Sci. 2005, 5, 21-28.

27. Kwok, A.Y.; Wilson, J.T.; Coulthart, M.; Ng, L.K.; Mutharia, L.; Chow, A.W. Phylogenetic study and identification of human pathogenic Vibrio species based on partial hsp60 gene sequences. Can. J. Micriobiol. 2002, 48, 903-910.

28. Maugeri, T.L.; Carbone, M.; Fera, M.T.; Gugliandolo, C. Detection and differentiation of Vibrio vulnificus in seawater and plankton of coastal zone of the Mediterranean Sea. Res. Microbiol. 2006, 157, 194-200.

29. Kim, Y.B.; Okuda, J.; Matsumoto, C.; Takahashi, N.; Hashimoto, S.; Nishibichi, M. Identification of Vibrio parahaemolyticus strains at the species level by PCR targeted to the toxR gene. J. Clin. Microbiol. 1997, 37, 1173-1177.

30. Wong, R.S.; Chow, A.W. Identification of enteric pathogens by heat shock protein60kDa (HSP60) gene sequesnces. FEMS Microbiol. Lett. 2002, 206, 107-113.

31. Chakraborty, R.; Sinha, S.; Mukhopadhyay, A.K.; Asakura, M.; Yamasaki, S.; Bhattacharya, S.K.; Nair, G.; Ramamurthy, T. Species-specific identification of Vibrio fluvialis by PCR targeted to the conserved transcriptional activation and variable membrane tether regions of the tox $R$ gene. J. Med. Microbiol. 2006, 55, 805-808.

32. Uddin, M.A.; Ullah, M.W.; Noor, R. Prevalence of Vibrio cholerae in human, poultry, animal excreta and compost samples. Stamford J. Microbiol. 2013, 2, 38-41.

33. Lin, M.; Schwarz, J.R. Seasonal shifts in population structure of Vibrio vulnificus in an estuarine environment as revealed by partial $16 \mathrm{~S}$ ribosomal DNA sequencing. FEMS Microbiol. Ecol. 2003, 45, 23-27.

34. Maugeri, T.L.; Carbone, M.; Fera, M.T.; Irrera, G.P.; Gugliandolo, C. Distribution of potentially pathogenic bacteria as free living and plankton associated in a marine coastal zone. J. Appl. Microbiol. 2004, 97, 354-361. 
35. Gugliandolo, C.; Carbone, M.; Fera, M.T.; Irrera, G.P.; Maugeri, T.L. Occurrence of potentially pathogenic vibrios in the marine environment of the Straits of Messina (Italy). Mar. Pollut. Bull. 2005, 50, 692-697.

36. Sousa, O.V.D.; Vieira, R.H.S.D.F.; Menezes, F.G.R.D.; Reis, C.M.F.D.; Hofer, E. Detection of Vibrio parahaemolyticus and Vibrio cholerae in oyster, Crassostrea rhizophorae, collected from a natural nursery in the Cocó river estuary, Fortaleza, Ceará, Brazil. Rev. Inst. Med. Trop. Sao Paulo 2004, 46, 59-62.

37. Harvell, C.D.; Kim, K.; Burkholder, J.M.; Colwell, R.R.; Epstein, P.R.; Grimes, D.J.; Vasta, G.R. Emerging marine diseases-Climate links and anthropogenic factors. Science 1999, 285, 1505-1510.

38. Kelly, M.T.; Dan Stroh, E.M. Occurrence of Vibrionaceae in natural and cultivated oyster populations in the Pacific Northwest. Diagn. Microbiol. Infect. Dis. 1988, 9, 1-5.

39. Liang, P.; Cui, X.; Du, X.; Kan, B.; Liang, W. The virulence phenotypes and molecular epidemiological characteristics of Vibrio fluvialis in China. Gut 2013, 5, doi:10.1186/1757-4749-5-6.

40. Daniels, N.A.; Shafaie, A. A review of pathogenic Vibrio infections for clinician. Infect. Med. 2000, 17, 665-685.

41. Elhadi, N.; Radu, S.; Chen, C.H.; Nishibuchi, M. Prevalence of potentially pathogenic Vibrio species in the seafood marketed in Malaysia. J. Food Prot. 2004, 67, 1469-1475.

42. Ji, H.; Chen, Y.; Guo, Y.; Liu, X.; Wen, J.; Liu, H. Occurrence and characteristics of Vibrio vulnificus in retail marine shrimp in China. Food Control 2011, 22, 1935-1940.

43. Yano, Y.; Yokoyama, M.; Satomi, M.; Oikawa, H.; Chen, S. Occurrence of Vibrio vulnificus in fish and shellfish available from markets in China. J. Food Prot. 2004, 67, 1617-1623.

(C) 2014 by the authors; licensee MDPI, Basel, Switzerland. This article is an open access article distributed under the terms and conditions of the Creative Commons Attribution license (http://creativecommons.org/licenses/by/3.0/). 